\title{
PEMANFAATAN PENINGGALAN SEJARAH DI RIAU MENUJU DAERAH EKOEDUWISATA
}

\author{
Wilaela \\ Universitas Islam Negeri Sultan Syarif Kasim Riau \\ wilaela@uin-suska. ac.id
}

\begin{abstract}
Utilization of historical relics in the Riau region has a foundation in Law No. 11 of 2010 in the spirit of preservation of cultural heritage. Preservation requires the use, utilization and necessity of community involvement. Every effort to use cultural heritage must pay attention to the preservation of nature and the surrounding environment. Educational aspects for each tourism policy must be included and included in the curriculum and learning in schools. In Riau, efforts have been made to make a complete cultural heritage with its eco-tourism as part of tourist destinations. These efforts are carried out by the community, both individually and in the form of communities. $V$ arious efforts that are growing in this area require guidance and assistance from the government. There are groups of people who are active in the utilization of historical heritage, but they have not received attention and have not been cooperated by the government in order to develop the people's economy through ecotourism. preservation of cultural heritage. There are focus and priority, such as Siak Regency, but there are some who still have not relied on the nature-based tourism sector as a regional asset. However, in various circles, both government and society, the desire to make historical heritage as an eco-tourism destination is growing.
\end{abstract}

Keywords: historical heritage, cultural heritage, preservation, utilization, ecotourism, Riau.

\begin{abstract}
Abstrak
Pemanfaatan peninggalan bersejarah di daerah Riau memiliki landasan pada Undang-Undang No. 11 Tabun 2010 dalam semangat pelestarian cagar budaya. Pelestarian mensyaratkan adanya pemanfaatan, pemanfaatan meniscayakan keterlibatan masyarakat. Setiap upaya pemanfaatan cagar budaya haruslah memperhatikan kelestarian alam dan lingkungan sekitar. Aspek edukasi untuk setiap kebijakan wisata harus ada dan dimasuke.en ke dalam kurikulum dan pembelajaran di sekolah. Di Riau, sudah mulai bermunculan upaya menjadikan cagar budaya lengkap dengan ekoeduwisatanya sebagai bagian destinasi wisata. Upaya-upaya ini dilakukan oleh masyarakat, baik secara mandiri perorangan maupun dalam bentuk komunitas. Berbagai upaya yang sedang tumbuh inimemerlukan bimbingan dan dampingan dari pemerintah. Ada kelompok masyarakat yang aktif dalam pemanfaatan peninggalan sejarah, tetapi mereka belum mendapat perhatian dan belum digandeng oleh pemerintah dalam rangka membangun ekonomi rakyat melalui ekoeduwisata. Kebijakan pemerintah daerah di Riau berbeda-beda terkait dengan pelestarian cagar budaya. Ada yang fokus dan prioritas, seperti Kabupaten Siak, namun masih ada yang terkesan belum mengandalkan sek.tor pariwisata yang berbasis alam sebagai aset daerah. Namun, di berbagai kalangan, baik pemerintah maupun masyarakat, mulai tumbuh hasrat untuk menjadikan peninggalan sejarah sebagai aset destinasi ekoeduwisata.
\end{abstract}

Kata Kunci: peninggalan sejarah, cagar budaya, pelestarian, pemanfaatan, ekoeduwisata, Riau.

\section{PENDAHULUAN}

Daerah Riau memiliki banyak peninggalan bersejarah yang diduga sebagai cagar budaya. Keberadaan benda-benda tersebut tidak semua diketahui dan dipedulikan. Ketidaktahuan masyarakat bisa menjadi salah satu faktor pembiaran masyarakat terhadap peninggalan bernilai sejarah sekaligus bernilai arkeologis tersebut. Pemerintah yang belum memberi perhatian sepenuhnya kepada pelestarian cagar budaya juga berdampak kepada punahnya peninggalan tersebut. Padahal, peninggalan bersejarah tidak hanya bernilai bagi pengembangan kesejarahan daerah Riau, tetapi juga berdampak kepada aspek kesejarahan, lingkungan sosial, budaya,ekonomi, pendidikan dan lain-lain. 
Adakonsep ahli sejarah ketimuran Bernard Lewis (2009) yang dapat dipakai untuk membaca fenomena berbagai upaya pelestarian peninggalan sejarah oleh berbagai pihak dewasa ini. Menurut Lewis, adanya upaya tersebut, baik yang berupa gagasan, tindakan atau perilaku, maupun budaya bendawi, tetap berada dalam sistem budaya yang masih berlaku di tengah masyarakat. Hal ini disebut denganremembered. Seringkali, karya budaya yang hendak dilestarikan itu pernah diabaikan atau ditinggalkan, tetapi kemudian ditemukan kembali, disebut denganrecovered. Selanjutnya, karena nilai-nilai karya budaya itu dianggap penting, maka karya budaya itu dimasukkan kembali dalam sistem budaya yang berlaku saat ini dengan tujuan untuk membangkitkan semangat dan kebanggaan masyarakat masa kini tentang sejarah, atau juga sebagai tujuan wisata. Upaya terakhir ini disebut dengan (invented.

Dewasa ini, bermunculan fenomena di berbagai daerah di Indonesia bahkan dunia untuk menawarkan wisata sejarah atau wisata pendidikan dan wisata lingkungan. Ini menunjukkan adanya keinginan untuk mengangkat kejayaan masa lalu untuk dilestarikan melalui pemanfaatannya sebagai bagian dari pendidikan dan wisata. Perlu dikaji bagaimana Riau dalam euforia menawarkan keunggulan lingkungan alam tersebut. Siapa, apa dan bagaimana upaya yang telah dan tengah dilakukan di Riau dalam rangka pelestarian sekaligus pemanfaatan peninggalan sejarah menuju Riau sebagai destinasi ekowisataeduwisata (selanjutnya ditulis ekoeduwisata)?

Studi ini diharapkan memiliki manfaat sebagai sumbangan bagi khazanah kajian sejarah dan arkeologi tentang Riau dan diharapkan dapat menjadi bahan masukan bagi dinas atau instansi terkait untuk menyusun program dan kebijakan. Bagi pengelola peninggalan sejarah, semoga studi ini memberikan konsep manajemen pengelolaan benda yang diduga sebagai cagar budaya. Sehingga, benda-benda tersebut tidak hanya sebagai onggokan puing yang tidak menarik atau bahkan dihindari. Bagi masyarakat yang berada di sekitar lokasi, semoga hasil penelitian ini nanti dapat membantu dalam upaya peningkatan tenaga kerja dan ekonomi mereka. Bagi dunia pendidikan, cagar budaya merupakan kegiatan pembelajaran outdoor yang perlu dirangcang serius di dalam kurikulum.

Penelitian tentang peninggalan bersejarah seperti cagar budaya di Riau umumnya terbatas dilakukan oleh instansi terkait, seperti Badan Pelestarian Cagar Budaya (BPCB) Batusangkar yang meliputi wilayah kerja Sumatera Barat, Riau dan Kepri, Balai Arkeologi (Balar) di Medan atau oleh pribadi-pribadi dengan keilmuan terkait. Oleh karena itu, dapat dikatakan bahwa kajian tentang peninggalan sejarah seperti cagar budaya menjadi ekslusif dan terbatas.

Sekalipun terbatas, kajian tentang peninggalan sejarah telah lama berlangsung dan tetap dilakukan hingga saat ini. Berbagai hasil penelitian dan publikasi para ahli telah menjadi rujukan untuk kajian-kajian berikutnya tentang sejarah dan kepurbakalaan di Riau. Diantaranya adalah karya Prof. Dr. Schnitger. Ph. D, Forgotten Kingdoms in Sumatra, Brill Archive; J. L. Moens menulis tentang Srivijaya Yva en Katanadi dalam Tijdschrift Voor Indische Tall,Land en Volkenkunde. Jilid LXXVII, 1937. Selain itu, ada J. W. Yzerman. Beschrijuing Van die Boeddhistische Boumwerken te Moeara Takoes. 1989;Cortesão, A. (1944), The Suma Oriental of Tomé Pires, London: Hakluyt Society, 2 vols. ;Haan, F. de, (1896), Naar midden Sumatra in 1684, Batavia-'s Hage, Albrecht \& Co. -M. Nijhoff. 40p. 8vo wrs. Tijdschrift voor Indische Taal-, Land- en Volkenkunde, Deel 39; dan Holle, G. Du Rij Beest. 1879. Beschrijving van de Hindoe OudhedenMoeara Takoes XII Kotta Kampar. Tijdschrift Voor Indische Tall,Land en Volkenkunde. XXV.

Selain itu, karya-karya tentang arkeologi antara laindatang dari arkeologSoekmono, R. , (2002), Pengantar sejarah kebudayaan Indonesia 2, Kanisius, ISBN 979-413-290-X dan karya disertasinya berjudul Candi, Fungsi dan Pengertiannya,Balai Arkeologi Medan. 1998. Berkala ArkeologiSangkhakala; Ada juga kajian dari Departemen Pendidikan dan Kebudayaan. 1996 tentangHasil Pemugaran dan Temuan Benda Cagar Budaya PSP I. Proyek Pembinaan Peninggalan Sejarah dan Kepurbakalaan Pusat di Jakarta. Ada tulisan dari Haryono, Timbul. 1986. Relief dan Patung Singa Pada Candi-Candi Periode Jawa Tengah, Penelitian atas Fungsi dan Pengertiannya. Yogyakarta: Penelitian Atas Fungsi dan Pengertiannya. Laporan PenelitianSiagian, 
Renville tahun 2002 dengan judulCandi sebagai Warisan Seni dan Budaya Indonesia. Yogyakarta: Yayasan Cempaka Kencana.

Buku tentang Riau yang menjadi buku "babon" dalam historiografi Riau adalah Sejarah Riau yang disusun oleh Muchtar Lutfi dkk (editor) pada tahun 1977 dan diterbitkan oleh Pemerintah Provinsi Riau. Buku ini bercerita tentang sejarah Riau dari masa awal, yaitu zaman batu hingga abad ke-20. Termasuk di dalamnya menyinggung tentang pengaruh agama Hindu dan Budha di Riau, dimana peninggalannya diwakili oleh Percandian Muara Takus. Buku lainnya adalah karya Prof. Suwardi MS dan Kamaruddin, tentang Sejarah Lokal Riau, Pekanbaru tahun 2016. Khusus untuk penjelasan tentang daerah Senapelan, digunakan buku karya Suwardi MS, Wan Ghalib, Isjoni. Dari Batin Senapelan ke Bandaraya Pekanbaru tahun 2004; dan karya ilmiah tesis tentang arsitektur dan sosiologi perkotaan khusus kasus Senapelan oleh Yohannes Firzal. Selain itu, ada hasil riset khusus tentang kawasan Pasar Bawah di Senapelan oleh Hery Suryadi, Tuti Khairani, Auradian Marta. Kebijakan Revialisasi Kawasan Pasar Bawah Sebagai Kawasan Wisata Cagar Budaya di Kota Pekanbaru, dipublish online oleh Fisipol Universitas Riau tahun2016 viahttp://repository. uinri. ac. id/. Masih tentang Senapelan, karya Sri Sugiharta dan Agoes Tri Mulyono. "Warisan Arkeologi Perkotaan di Kawasan Bandar Senapelan" dalam Sri Sugiharta. Sumatera Silang Budaya: Kontestasi NilaiNilai Historis, Arkeologis, dan Antropologis serta Upaya Pelestarian Cagar Budaya. Buku ini diterbitkan oleh BPCB Batusangkar tahun 2017.

Umumnya karya yang ada bercerita tentang keberadaan cagar budaya sebagai hasil inventarisasi dan dokumentasi. Ada karya terkait yang memasukkan perspektif, misalnya sejarah, arsitektur atau tata kota. Penelitian yang khusus membahas tentang pemanfaatan kawasan cagar budaya, seperti Pasar Bawah adalah penelitian oleh Hery Suryadi dan kawan-kawan sebagaimana disebutkan di atas. Adapun tulisan ini merupakan hasil penelitian yang mencoba mendeskripsikan upaya yang telah dan sedang dilakukan dalam rangka pelestarian peninggalan sejarah, baik sebagai cagar budaya maupun diduga cagar budaya, dan pemanfaatannya menuju Riau ekoeduwisata.
Karya lainnya yang khusus berbicara tentang ekowisata ataupun eduwisata bersifat nasional, tidak ada hubungannya dengan daerah Riau, tetapi dimanfaatkan sebagai referensi untuk perbandingan dan penguat konsep ekoeduwisata. Diantaranya adalah artikel dalam jurnal, misalnya. Ermiliansa, Dedien, Adji Samekto, and Hartuti Purnaweni. "Peran Prenjak Dalam Mewujudkan Daerah Konservasi Berbasis Eco Edu Wisata Mangrove di Dusun Tapak, Tugurejo, Kota Semarang. " Ekosains 6.1 (2014). Konsep tentang eduwisata juga terdapat dalam tulisan Maria Zewita dengan judul Kajian Sumberdaya Perairan Situ IPB bagi Pengembangan Eduwisata di Kampus IPB, Dramaga, Bogor, 2010. Tulisan serupa yang dimanfaatkan untuk memperkaya konsep eduwisata adalah karya sHalim FR. 2013. "Fasilitas Eduwisata Sejarah Perjuangan Kota Surabaya". eDimensi Arsitektur Petra 1. 2 (2013): 118-124.

Kajian ini bersifat kualitatif, yaitu kajiandeskriptif dan menggunakan analisis dengan pendekatan induktif. Kualitas hasil temuan dari studi kualitatif secara langsung tergantung pada kemampuan, pengalaman dan kepekaan dari interviewer atau moderator group. Metode penelitian yang digunakan untuk dapat menjawab seluruh pertanyaan kajian ini adalah metode sejarah. Langkah-langkah metode sejarah menurut Garraghan (1957:33) dan Herlina (2008: 2), (Sjamsuddin, 2010) ada 5, yaitu:

Pertama, Heuristik sumber sejarah dan teknik pengumpulannya. Langkah pertama dalam metode sejarah setelah penentuan tema adalah penemuan dan pengumpulan sumber sejarah. Sumber sejarah dimaksud adalah sumber yang terkait dengan peninggalan dan tinggalan sejarah dan arkeologi yang telah ditetapkan sebagai cagar budaya atau yang masih diduga sebagai cagar budaya dan berada di wilayah Riau. Teknik pengumpulan data dilakukan dengan wawancara, observasi, dokumentasi, studi literatur/pustaka, dan focus group discussion. Sumber data penelitian kualitatif adalah informan dan dokumen. Sementara objek kajian adalah berbagai peninggalan, baik sebagai cagar budaya maupun yang diduga cagar budaya. Studi dilakukan di wilayah Riau, khususnya di daerah Kabupaten Kampar, Kabupaten Siak dan Pekanbaru. Ketiga daerah ini dianggap lebih dinamis dan tampak 
nyata tentang upaya masyarakat dalam rangka membuka peluang ekoeduwisata.

Kedua, Kritik Ekstern dan Intern: kegiatan kritik atau verifikasi ini adalah kegiatan untuk mendapatkan sumber yang otentik, kredibel atau dapat diandalkan. Dalam kalibrasi keabsahan data ini peneliti menggunakan triangulasi data dan triangulasi metode. Triangulasi data ini biasanya disebut dengan koroborasi dalam penelitian sejarah. Sementara teknik pengumpulan data bersifat triangulasi yaitu menggunakan berbagai teknik pengumpulan data secara gabungan atau simultan, yakni observasi berperan serta (participant observation) dalam kegiatan gorup terfokus dan wawancara mendalam (in depth interview) dengan para informan dan observasi lapangan. Ketiga, Analisis dan Sintesis, atau dalam istilah lain ada yang menyebutkan denganinterpretasi. Terakhir, keempat, Historiografi atau penyusunan narasi sejarah peninggalan dan upaya menuju ekoeduwisata.

\section{Pembahasan}

\section{Pelestarian}

Pelestarian dan kegiatan inventarisasi peninggalan sejarah seperti cagar budaya itu satu paket, karena kegiatan inventarisasi ini sama dengan kegiatan pendokumentasian dan pelestarian sebagaimana tertuang dalam UU No 11/2010 pasal 53 (4): bahwa pelestarian cagar budaya harus didukung oleh kegiatan pendokumentasian sebelum dilakukan kegiatan yang dapat menyebabkan terjadinya perubahan keasliannya.

Pelestarian peninggalan sejarah berjenis cagar budaya harus berorientasi pada kepentingan cagar budaya yang berdampak positif pada masyarakat. Pelibatan masyarakat dalam pelestarian cagar budaya diharapkan dapat memberikan manfaat positif pada pelestarian cagar budaya itu sendiri. Keterlibatan masyarakat mutlak, karena tujuan dari pengelolaan cagar budaya dan manfaatnya adalah untuk peningkatan kesejahteraan masyarakat. Keterlibatan masyarakat dalam pengelolaan cagar budaya merupakan amanat UndangUndang Cagar Budaya.
Paradigma pengelolaanpeninggalan sejarah tidak lagi hanya ditujukan untuk kepentingan akademik semata, tetapi harus meliputi kepentingan pelestarian alam atau lingkungan dan peningkatan ekonomi atau kesejahteraan masyarakat sekitar. Oleh karena itu, pemanfaatan cagar budaya memerlukan sinergitas antara pemerintah, akademisi, masyarakat dan juga sektor swasta. Pemerintah perlu mengambil peran sebagai fasilitator dan mediator dalam pengelolaan dan pemanfaatan cagar budaya. Keterlibatan masyarakat menjadi penting dalam pengelolaan cagar budaya yang berwawasan pelestarian.

Menurut Tanudirjo (2003), keterlibatan masyarakat secara aktif diperlukan agar mereka pun memperoleh manfaatnya dari pengelolaan peninggalan sejarah. Konsep ini dipakai untuk melindungi dan mengatur dalam upaya pelestarian sumberdaya budaya dan nilai-nilai yang dikandungnya serta keaslian lingkungan masa lalu. Masyarakat dapat berperan aktif, mandiri, mengambil inisiatif dan proaktif dalam kegiatan pelestarian. Masyarakat yang diharapkan dapat berpartisipasi aktif adalah masyarakat di daerah dimana peninggalan sejarah seperti cagar budaya terdapat. Komunitas pecinta cagar budaya setempat akan menekankan programnya kepada aksi nyata. Masyarakat secara swadaya merencanakan, merumuskan, melaksanakan dan mengevaluasi kegiatan mereka. Biasanya selalu ada penggerak di dalam setiap komunitas. Figur penggerak ini adalah pemimpin yang akan mengarahkan dan membimbing komunitasnya.

\section{Peran Masyarakat}

Dalam UU No. 11 Tahun 2010 tentang Cagar Budaya pasal 1 (22) disebutkan defenisi pelestarian adalah "upaya dinamis untuk mempertahankan cagar budaya dan nilainya dengan cara melindungi, mengembangkan dan memanfaatkannya". Dalam Pasal 1 (33) dinyatakan bahwa "Pemanfaatan adalah pendayagunaan cagar budaya untuk kepentingan sebesar-besarnya kesejahteraan rakyat dengan tetap mempertahankan kelestariannya". Terkait pemanfaatannya, pasal 88 menyebutkan:

1) Pemerintah, Pemerintah Daerah, dan setiap orang dapat memanfaatkan Cagar Budaya 
untuk kepentingan agama, sosial, pendidikan, ilmu pengetahuan, teknologi, kebudayaan, dan pariwisata.

2) Pemerintah dan Pemerintah Daerah memfasilitasi pemanfaatan dan promosi Cagar Budaya yang dilakukan oleh setiap orang.

3) Fasilitasi sebagaimana dimaksud pada ayat (2) berupa izin pemanfaatan, dukungan Tenaga Ahli Pelestarian, dukungan dana, dan/atau pelatihan.

4) Promosi sebagaimana dimaksud pada ayat (2) dilakukan untuk memperkuat identitas budaya serta meningkatkan kualitas hidup dan pendapatan masyarakat.

Pasal 85 point 1) kalimat "setiap orang dapat memanfaatkan" memberi landasan keterlibatan masyarakat dalam pemanfaatan cagar budaya. Di Riau, pelibatan masyarakat menjadi penting mengingat sumber daya alam di Riau sebagian besar bergantung kepada sumber daya alam yang tidak dapat diperbaharui. Namun sayangnya, masyarakat belum benar-benar terlibat, karena beberapa faktor, di antaranya karena ketidaktahuan tentang bagaimana cara mengelolapeninggalan bsersejarah, dan belum adanya kerjasama antara pemerintah dan masyarakat. Ada di antara masyarakat yang memiliki gambaran tentang apa yang harus dilakukan dalam rangka pemafaatan cagar budaya dan potensi alam lainnya. Mereka menggagas untuk membentuk komunitas sesama pemerhati peninggalan sejarah. Di antara kelompok itu, ada yang berada di Siak, di Pekanbaru dan di Kampar. Mereka bergerak sendiri-sendiri dan belum bekerja sama dengan pemerintah atau pemerintah belum melihat mereka sebagai mitra.

\section{Geliat Pekanbaru}

Pekanbaru sebagai ibukota Provinsi Riau menjadi barometer bagi kabupaten/kota di Riau. Pekanbaru juga merupakan kota lama yang memiliki sejarah panjang sejak abad ke-18, sejak bernama Senapelan. Sehingga, sangat nyata keberadaan berbagai peninggalan kejayaan masa lalu tersebut. Komunitas pemerhati sejarah atau pencinta lingkungan tumbuh mengiringi dinamika Pekanbaru, yang bersuhu panas dan minimnya ruang hijau terbuka. Berbagai komunitas ini sering 'memamerkan' keberadaan mereka di car free day(CFD) yang biasanya diadakan rutin setiap hari ahad di seputar Jalan Diponegoro dan Jalan Gajahmada Pekanbaru. Di Pekanbaru, selain mengambil tempat di sekitar pusat administrasi pemerintahan Provinsi Riau atau bundaran tugu zafin, CFD juga diadakan di sekitar Main Stadion di Jalan Melati, Panam. Di kedua tempat ini secara bergantian, dapat disaksikan adanya berbagai komunitas atau kumpulan para pencinta lingkungan sekaligus komunitasantiquarian sepeda ontel. Mereka ingin memperkenalkan kegiatan bersepeda sebagai alternatif berkendaraan bermotor. Bersepeda terkait dengan olahraga, sehat dan udara yang bersih. Di antara mereka ada yang sekaligus mengkampanyekan menyayangi pohon. Anggota komunitas sepeda ontel ini cair dan tidak mengikat. Mereka lintas usia, suku dan latar pekerjaan.

Terkait dengan peninggalan sejarah adalah komunitas dan gerakan Pekanbaru Heritage $W$ alk. Komunitas ini lebih fokus kepada kegiatan memperkenalkan objek peninggalan sejarah terutama di daerah Senapelan. Kegiatan mereka lebih dekat kepada historical touring. Pesertanya juga bersifat tidak mengikat. Mereka disatukan oleh hobby yang sama, yaitu traveller dan kecintaan terhadap berbagai peninggalan sejarah dan budaya, termasuk kuliner.

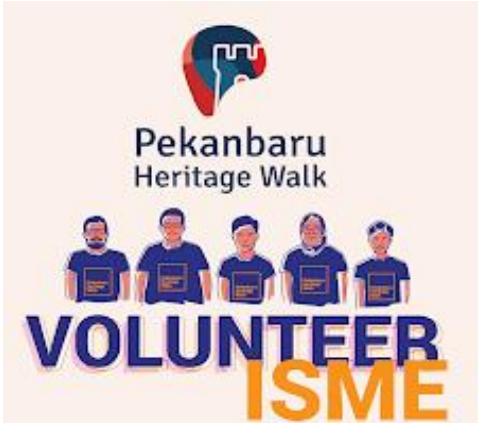

Gambar 1. Logo Komunitas PHW

Pekanbaru Heritage $W$ alk atau disingkat PHW merupakan komunitas atau gerakan yang mengajak orang-orang untuk menjelajahi sambil memperkenalkan berbagai peninggalan bersejarah di Pekanbaru. Komunitas ini digagas antara lain oleh Bayu Amde Winata, Mike Agnesia, Refki Riyantori, Iwan Syawal dan Yuli Nasution. Bayu Amde Winata adalah travel 
photographer and mobile journalist eksecutor. Mike Agnesia, seorang pegawai negeri sipil yang memiliki kegeramaran sebagai backpacker bertindak sebagai public relations sekaligus concept inisiator PHW. Sementa Iwan Syawal adalah senior tour guide juga sebagai public relations. Adapun Yuli Nasution bertindak sebagai tour guide traffic and financial.

Komunitas ini memusatkan kegiatan mereka di Kampung Bandar, Senapelan. Meurut info di Riau Magazin, sedikitnya ada sekitar 1500-an orangtelah berpartisipasi dalam PHW. Sebagai organisasi, sifatnya longgar dan tidak memiliki struktur yang mengikat. Para penggiat ini bekerja dalam komunitas sesuai keahlian masing-masing. Menurut Iwan Syawal, pada awalnya PHW adalah nama bagi kegiatan yang diselenggarakan pada 11 Maret 2017. Kegiatan tersebut mengajak orang untuk lebih mengenal kawasan lama bersejarah di Pekanbaru. Atas sambutan luar biasa dengan kegiatan ini, kemudian Pekanbaru Heritage Walk juga dikenal sebagai nama bagi sebuah komunitas, sekaligus juga gerakan yang konsentrasinya adalah memajukan kawasan lama Pekanbaru dengan mimpi mewujudkan sudutsudut kawasan lama ini menjadi new cultural center. PHW secara aktif kampanye pada Januari 2018, dengan mengajak lebih banyak pihak dan komunitas lain untuk berkolaborasi dan mewujudkan karyanya di tempat ini.

Sebagai gerakan yang memilih tourisme sebagai pendekatan, Pekanbaru Heritage Walk lebih menempatkan diri sebagai penghubung bagi siapa saja yang ingin menjadikan Pekanbaru menjadi kota yang lebih baik. Karenanya, Pekanbaru Heritage Walk juga memberikan perhatian lebih bagi society development, menyelenggarakan berbagai sharing class dan mewujudkan mimpi bersama melalui jalan donasi.

Di dalam komunitas atau gerakan PHW diharapkan ada semangat volunteering. Siapa saja yang bergabung diharapkan menjadi relawan sejati dalam mengambil bagian dan peran bagi sebuah pekerjaan yang selama ini mungkin terlalu besar untuk dikerjakan sendiri. Pekanbaru Heritage Walk, melalui konsep volunteering mengharapkan lebih banyak orang muda yang bergabung dan mengambil peranannya. Para volunteer dapat terlibat langsung mengenalkan khazanah kawasan lama Pekanbaru, berperan aktif dalam society development, belajar hal-hal baru, belajar mencintai peninggalan sejarah sambil bersenang-senang menikmati keindahan, menyebarkan semangat positif dan menghubungkan lebih banyak lagi orang untuk berkarya dan berkolaborasi demi kemajuan Kota Pekanbaru.

Kegiatannya berupa tur jalan kaki yang dikemas sebagai bagian dari eduwisata. Masyarakat peserta diberikan informasi tentang sejarah objek yang dikunjungi. PHW telah menulis artikel terkait dengan destinasi turmereka yang diberi judul "26 Lokasi Bersejarah di Kota Pekanbaru". Mereka berharap dengan tersosialisasinya berbagai objek bersejarah di Pekanbaru sekaligus akan tumbuh kepedulian kepada kelestarian peninggalan tersebut. Selain itu, dengan kegiatan mereka diharapkan perekonomian masyarakat juga akan meningkat dan berkembang.

Pihak PHW sedang berupaya untuk bersinergi dengan pihak pemerintah dan terkait. Namun, sejauh ini belum tampak pelibatan masyarakat sebagai penggerak ekonomi dalam kegiatan PHW. Mungkin karena usianya yang belum 1 tahun, sehingga komunitas dan gerakan ini masih memerlukan waktu untuk dapat lebih berkembang dan dipercayai sebagai motor penggiat ekonomi berbasis lingkungan sejarah.

Di daerah sekitar Parit Indah, tepatnya di Desa Sungai Geringging, Kulim di Pekanbaru, ada taman buah seluar \pm 29 ha, dimiliki dan dikelola masyarakat. Berbagai jenis tanaman buah terbuka untuk masyarakat untuk dipetik, seperti kelengkeng dan nangka. Satu dua rombongan anak-anak sekolah dengan dikoordinir oleh para guru mereka mendatangi tempat ini. Mereka memetik buah dengan gembira sambil mendengarkan penjelasan tentang khasiat buah bagi tubuh dan pertumbuhan mereka. Termasuk penjelasan tentangcara menanam dan merawat pohon buah, sampai kepada penjelasan tentang tanaman buah khas Papua, yaitu matoa(pometia pinnata) yang tumbuh subur di Pekanbaru.

Selain agrowisata yang tengah dikembangkan di Kulim dan belum tersosialisasi, di Pekanbaru di daerah sekitar kebun binatang di Kubang, terdapat juga taman untuk areal beristirahat keluarga. Hanya saja, daerah ini belum dikembangkan sebagai daerah agrowisata. 
Namun konsep pilihan kembali ke alam menjadi upaya yang ingin dikembangkan oleh pemiliknya. Sama halnya dengan wisata kebun salak di daerah Kulim juga upaya mengeksplorasi alam sekitar untuk tujuan wisata. Dapat diamati, bahwa mulai ada upaya-upaya menuju ekoeduwisata di Pekanbaru. Upaya tersebut tidak bisa disamakan dengan upaya simultan dan masif yang dilakukan oleh para investor. Karena, dari beberapa titik agrowisata dan ekowisata di atas adalah milik masyarakat dan semua merupakan upaya masyarakat atau komunitas. Hal ini justru sesuai dengan konsep pemanfaatan dan pelestarian dalam UU No 11 Tahun 2010 tentang cagar budaya. Pemanfaatan cagar budaya yang melibatkan peran masyarakat memangbelum tampak bersinergi dengan pemerintah Pekanbaru. Padahal, Pekanbaru memiliki sejumlah lokasi eduwisata, seperti Museum Daerah Sang Nila Utama, Taman Budaya, Gedung Teater Idrus Tintin, kawasan Senapelan, dan lain-lain yang dapat dikembangkan dan disinergikan dengan agrowisata. Ditambah lagi dengan kerinduan terhadap ruang terbuka dan alami oleh masyarakat kota besar seperti Pekanbaru, sehingga agroawisata dan museum serta taman budaya dapat menjadi alternatif kunjungan oleh masyarakat Pekanbaru. Pemerintah kota telah membangun ruang taman hijau (RTH) seperti di depan Rumah Dinas Walikota Jalan Ahmad Yani dan di seberang Kantor Walikota di Jalan Sudirman (bekas Taman Kaca Mayang). Namun, sekali lagi, pemanfaatannya belum maksimal menuju Pekanbaru ekoeduwisata.

\section{Agrowisata Pulau Belimbing, Kampar}

Di Kabupaten Kampar, tepatnya di desa Pulau Belimbing, ada program agrowisata yang menarik dicermati sebagai upaya komunitas menuju kawasan ekoeduwisata. Semangat anakanak muda di daerah untuk mengubah pola hidup masyarakatnya perlu diapresiasi. Mereka menjadikan replika rumah lontik sebagai tempat berkumpul atau kantor komunitas. Halaman bawah rumah dan sekitar rumah lontik ini mereka lengkapi dengan berbagai peralatan warisan budaya yang hampir jarang terlihat saat ini. Mereka bekerja secara swadaya dan swadana. Para pemuda di bawah komando Suparman dan
Manaf, memperkanalkan kepada masyarakat luas tentang wisata memetik jeruk. Konsepnya sama dengan wisata memetik apel di Batu Malang. Pengunjung dipungut bayaran Rp. 5. 000 per orang sebagai pas masuk kebun. Setiap pengunjung dapat memetik jeruk sambil makan buah asam manis berkulit tebal khas dari Kampar tersebut sepuasnya dan gratis. Jeruk hasil petikan ditimbang dan dihitung untuk dibayar. Harga per kilo sama atau sedikit lebih murah atau bahkan sedikit lebih mahal dari jeruk yang dijajakan di pinggir jalan atau di pasar tradisional. Jadi, keasyikannya adalah pada kegiatan memetik jeruknya plus singgah di rumah adat lama lontik untuk melihat dan mendengar harapan dan 'mimpi' besar anakanak muda, terkait dengan potensi daerah mereka.
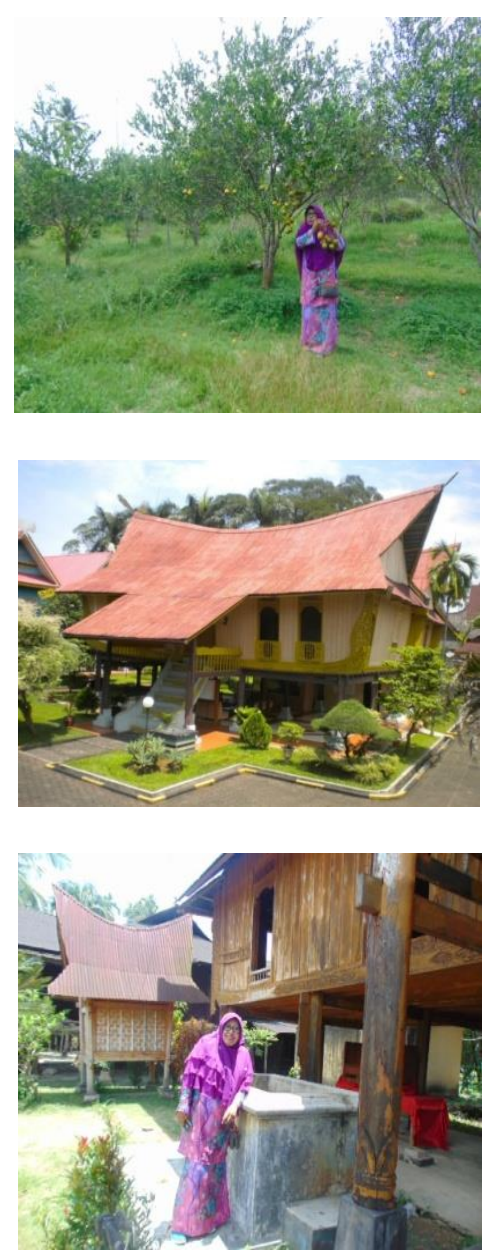

Gambar 2. Agrowisata Pulau Belimbing (atas) dan di Rumah Lentik (tengah \&bawah)

Manaf (21 tahun) yang merupakan mahasiswa dalam persiapan wisuda pada pertengahan 2017, menjelaskan bahwa komunitas menginginkan Kabupaten Kampar menjadi destinasi wisata. 
Yang mereka tawarkan adalah kunjungan ke berbagai objek wisata yang baru ditemukan, seperti Ulu Kasok yang disebut"Raja Empatnya Kampar”, Percandian Muara Takus, dan objek lainnya, yang diakhiri dengan kegiatan agrowisata memetik jeruk atau nanas, mencicipi kuliner khas Kampar dan membeli souvenir dan makanan oleh-oleh khas Kampar. Untuk itu, di Pulau Belimbing perlu ada outlet, dengan memanfaatkan replika rumah lontik. Ketika ditanyakan siapa yang menyiapkan semua itu, Manaf menyampaikan bahwa mereka sebagai pemuda asli di situ dapat menggerakkan masyarakat, terutama kaum ibu, untuk bekerjasama. Ibu-ibu yang membuat panganan oleh-oleh dan souvenir. Hal ini sudah mereka sampaikan, dan kaum ibu setuju dan mendukung. Sayangnya, rencana mereka ini belum direspon oleh pemerintah daerah. Suparman menyatakan bahwa sudah berkali-kali mereka mengajukan proposal, agar pemerintah membantu untuk pemberdayaan SDM atau untuk kelengkapan rumah lontik sebagai workshop. Mereka ingin diberi pelatihan atau mengikuti pelatihan di daerah-daerah yang dipandang telah berhasil memanfaatkan peninggalan historis dan budaya dan kelestarian lingkungan.

Rumah lontik sebagai peninggalan budaya mereka jadikan markas. Suparman menyatakan bahwa mereka agrowisata yang mereka kembangkan harus berbasis lingkungan mereka. Kebun-kebun masyarakat dan rumah lontik sebagai aset budaya harus dihubungkan dengan kegiatan agrowisata. Mereka juga mulai menata peninggalan tradisi seperti berbagai peralatan etnografika, kuliner dan souvenir. Suparman dan kawan-kawan mencoba membangun memori kolektif masyarakat setempat terhadap budaya masyarakat masa lalu mereka, misalnya dengan mengupayakan adanya alat penumbuk padi, dan lain-lain yang dipamerkan di sekitar rumah lontik. Apa yang dikatakan oleh Bernard Lewis (2009), bahwa mulai tumbuh kesadaran mereka tentang pentingnya mengangkat tradisi dan peninggalan masa lalu mereka (remembered). Untuk itu, komunitas anak-anak muda itu berusaha melakukan pelestarian dengan cara mengumpulkan berbagai benda budaya yang unik dan antik yang telah lama terlupakan. Termasuk dalam hal ini adalah penemuan penumbuk padi seperti lesung, alu antarnnya, dari kuliner sampai kepada keindahan alam (recovered). Pada masa lalu, benda-benda budaya tersebut telah digunakan. Namun, seiring perjalanan waktu, benda tersebut dilupakan, karena adanya pemakaian heler. Tatkala fenomena wisata sejarah berkembang, tiba-tiba alat penumbuk padi itu seperti ditemukan kembali. Semua itu, kemudian mereka pamerkan dalam suatu program agrowisata di Kampar (invented). Mereka juga mengimbau masyarakat setempat untuk membuat kuliner khas dan tradisi untuk ditawarkan ke masyarakat. Apa yang mereka cita-citakan tersebut sayangnya belum tersusun dalam suatu bangunan konsep dengan tahapan-tahapan yang jelas.

Ada kekhawatiran jika mereka patah semangat dan rencana mereka tinggal rencana. Peneliti menawarkan dapat membantu untuk membimbing dalam penyusunan proposal dan mengedit atau memperbaiki redaksi proposal, serta mengarahkan kemana proposal harus diajukan. Namun, sebagaimana PAR (participatoty action research) dilakukan, maka semua itu sifatnya fasilitator dan mediator. Komunitas sendiri yang menyusun proposal dengan perencanaan bertahap dan tujuan akhir, mengadakan audiensi dan presentasi dengan pejabat terkait, dan lainlain.

Selain agrowisata di Pulau Belimbing, Kampar dengan sebagian besar daerahnya dialiri Sungai Kampar dan sebagian lagi dilewati Sungai Siak mulai bangkit di sektor pariwisata air. Di antaranya misalnya Ulu Kasok, suatu objek wisata pemandangan alam yang indah, sebagai akibat pembangunan bendungan PLTA XIII Koto Panjang. Ada juga Sungai Hijau, dimana airnya tampak hijau karena pengaruh lumut, Taman Agrowisata Sungai Pinang, Gema di Kampar Kiri dan lain-lain. Semuanya merupakan usaha masyarakat.

\section{Siak Heritage Community}

Lain halnya dengan komunitas pemerhati khazanah Siak, yang bernamaSiak Heritage Community (SHC). Wan Putra atau Wan Syahputra, yang paling rajin melakukan sosialisasi tentang khazanah sejarah Siak. Anak muda ini memiliki cara sendiri untuk mendapatkan berbagai foto dan naskah tua. Dia mendapatkan sejumlah foto dokumentasi antik 
dan berharga tentang Kerajaan Siak dan Sultan Syarif Kasim II. Katanya ia peroleh dari masyarakat yang memiliki koleksi tersebut karena jabatan pada masa lalu atau karena diwariskan oleh kerabat yang memiliki hubungan dengan istana Kerajaan Siak. Komunitas ini juga sering mengikuti berbagai kegiatan yang diselenggarakan oleh Bupati atau Dinas Kebudayaan dan Pariwisata untuk memberi masukan yang diperlukan oleh pemerintah. Wan Putra dan kawan-kawan juga turut serta dalam pemberdayaan yang dilakukan oleh Dirjen Sejarah bekerjasama dengan Dinas PU Siak dalam rangka Siak Menuju Kota Pusaka. Tidak heran, bahwa Wan Putra dapat menjadi tourguide yang baik untuk berbagai objek destinasi wisata di Siak.

Pemerintah Siak menginginkan bahwa Siak menjadi Kota Hijau dan keinginan itu diupayakan, sehingga terasa ketika kita memasuki wilayah Siak Sri Inderapura. Kebersihan, hijau dan asrinya Siak dapat diacungi jempol. Bahkan ada wilayah agrowisata, dimana pengunjung dapat turut serta memanen madu sialang atau panen durian. Hutan wisata, terletak di jalan menuju Tangsi Militer Belanda yang berada di komplek Angkatan Darat Mempura. Jalanan pun beraspal dan dalam kondisi baik. Dapat dikatakan bahwa dari aspek sarana dan prasarana, Siak telah mumpuni menjadi kota tujuan wisata. Jalan, jembatan, taman, masjid dan Islamic Center telah dikondisikan sedemikian rupa. Kota tua dan bersejarah dipelihara, seperti Cina Town. Sayangnya, Pemda melakukan pengecatan warna merah semua untuk wilayah yang disebutnya dengan China Town ini, warna yang sama dengan warna kelentengHouk Siok Kong yang terdapat di situ. Secara historis, China Town adalah nama yang diberikan belakangan dalam rangka menggiatkan pariwisata. Tetapi, secara historis, bukan berarti tidak ada unsur melayu di wilayah tersebut. Dengan mengecatnya menjadi warna merah seolah-seolah daerah itu memang peninggalan etnis China saja perlu dikaji kembali, agar kegiatan renovasi atau pemberian namaChina Town saat ini tidak ahistoris.

Rumah makan mulai menjamur dengan menu dan harga yang variatif tanpa meninggalkan menu asli Siak. Kepala Bidang Kebudayaan dan Pariwisata, Pak Mahadar, M. Si menyatakan bahwa Siak sekarang tidak hanya mengandalkan objek wisata, tetapi juga kulinernya. Jika dulu orang terlanjur menganggap bahwa harga-harga makanan di Siak jauh lebih mahal daripada di Pekanbaru, maka sekarang pemerintah menganjurkan kepada pihak pengelola rumah makan untuk menyesuaikan harga dan variatif. Pengunjung dapat memilih sendiri jenis makanan dengan harga tertentu. Jika menginginkan asam pedas bawung atau tapa, tentu harus mengeruk kocek lebih dalam dibandingkan dengan nasi ramas lauk ayam kota.

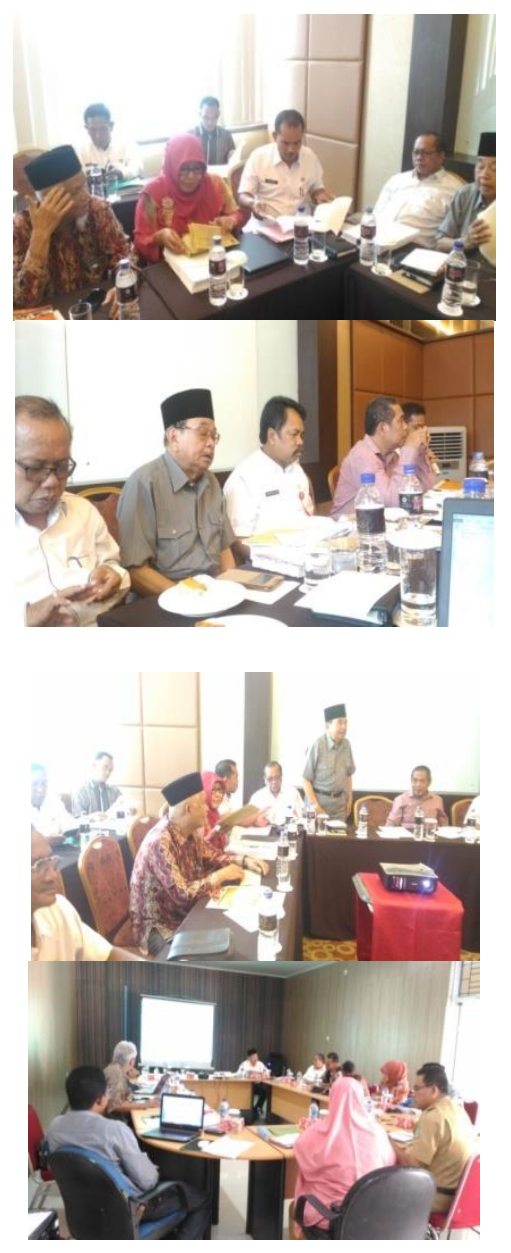

Gambar 3 Diskusi tentang peninggalan sejarah berupa cagar budayau ntuk mendapatkan masukan dari stakeholder dengan Kadisdikbud Kabupaten Siak dan Ketua LAM Riau

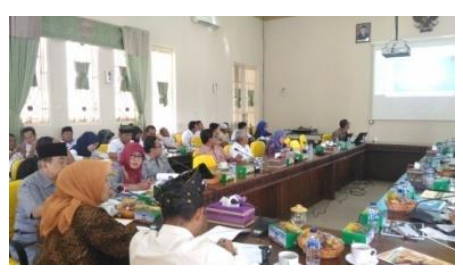




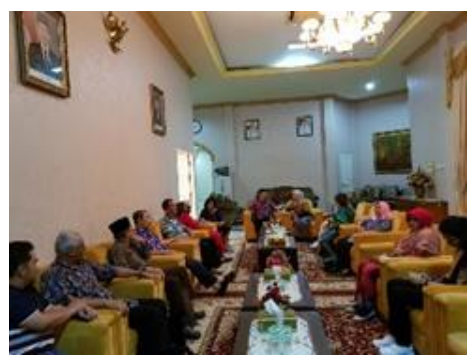

Gambar 4. Diskusi peninggalan sejarah berupa cagar budaya untuk mendapatkan masukan dari Sejarawah Prof. Suwardi MS. bersama Pemerintah Siak.

Pemanfaatan cagar budaya haruslah berwawasan pelestarian dan adanya keterlibatan masyarakat secara aktif. Komunitas pemerhati cagar budaya merupakan bentuk nyata partisipasi aktif masyarakat. Di antara komunitas pemerhati cagar budaya yang kami temui adalah Siak Heritage Community (CHS) dengan personil Wan Saputra (30 tahun) dan kawan-kawan. Mereka aktif mengikuti berbagai kegiatan terkait dengan pelestarian khazanah Siak. Umumnya mereka hadir ketika pemerintah Siak mengadakan pertemuan terkait dengan cagar budaya dan program lingkungan di Siak. Mereka aktif memperkenalkan Siak dengan cara memposting berbagai foto dokumentasi Siak masa lalu di media sosial seperti facebook. Kegiatan ini nampak remeh dan mirip-mirip trend. Namun, apa yang mereka lakukan adalah menunjukkan kepedulian mereka terhadap sejarah dan budaya daerahnya. Masa kejayaan Kerajaan Siak tidak cukup dibaca dari buku, tetapi harus diperkenalkan melalui media daring yang memang popular saat ini. Mengingat tidak ada lagi tradisi bertutur atau bercerita tempat generasi menerima khazanah masa lalu, maka postingan foto melalui medsos dan blog menjadi sesuatu yang bernilai positif. Foto yang diposting dalam akun facebook Wan Putra adalah koleksi terbatas dan oldiest, kadang-kadang merupakan koleksi pribadi yang susah ditemukan saat ini. Uniknya, Wan Putra dipercayakan oleh orang untuk menyimpan koleksi langka mereka.
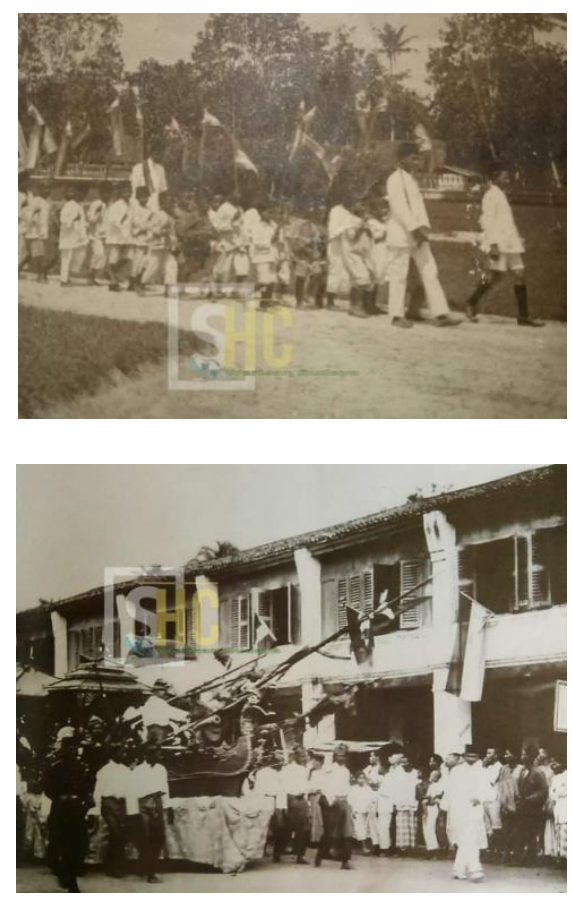

Gambar 5. Foto-foto di atas hasil postingan akun facebook "Siak Heritage Community".

\section{Tapung Heritage}

Tapung Heritage adalah komunitas pemerhati sejarah di daerah Tapung dengan motto 'merajut sejarah menjulang marwah". Organisasi ini berbadan hukum resmi. Mereka juga memiliki keinginan melakukan pelestarian terhadap khazanah Tapung dan melakukan protes terhadap kebijakan Pertaminadengan melakukan penolakan atas klaim makam oleh pertamina, yang mereka anggap tidak bernilai historis dan tidak berangkat dari budaya Tapung. Mereka juga memiliki komitmen memperhatikan sejarah Tapung, sehingga berbagai kebijakan baik pemerintah maupun swasta, yang menyalahi sejarah, akan mereka kritisi. Salah seorang anggotanya, Habibi, rajin berdiskusi untuk mencari dukungan pelestarian.

Gubernur Masyarakat Tapung ingin mendapat perhatian pemerintah dalam hal pembangunan daerah mereka. Mulai dari infrasturktur, pendidikan dan keinginan masyarakat tempatan menjadikan daerah mereka di Kasikan Tapung Hulu sebagai kampong heritage. Potensi alam seperti perkebunan cukup menjanjikan di daerah ini. Sehingga, jika kampong heritage dapat terwujud, mereka ingin memadukannya dengan ekowisata. Keinginan agar daerah Tapung menjadi Kampong Heritage 
didasari bahwa daerah Tapung sebagai hulu dari Sungai Siak menyimpan banyak peninggalan sejarah, baik dari Kerajaan Siak maupun kerajaan-kerajaan kecil lainnya yang ada di Tapung. Tapung Heritage keberatan dan menuding pihak PTPN V melakukan pengaburan sejarah di Desa Sinamanenek Kabupaten Kampar Riau. Di areal perkebunan Sei Berlian, Sinamanenek, Kabupaten Kampar, PTPN B membangun dan merenovasi sebuah makam yang oleh warga di sekitar yang tidak diketahui jelas asal-usulnya olehwarga setempat. Sebaliknya, masih di areal di areal perkebunan, PTPN B menelantarkan makam tua seorang datuk yang menjadi tokoh berpengaruh di masa lalu.

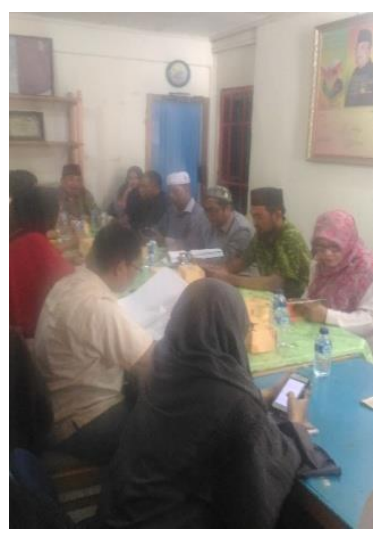

Gambar 6. Dialog bersama Tapung Heritage

(Dok. Pribadi, 2017)

\section{Ekoeduwisata}

Kajian tentang peninggalan sejarah cagar budaya dalam konsep yang sedang popular adalah kajian ekoeduwisata. Pengertian ekoeduwisata justru banyak dikaitkan dengan pelestarian cagar budaya dengan tetap mengutamakan konsep bergaul dengan lingkungan dan untuk dimanfaatkan dalam dunia pendidikan. Demikian yang kami maksudkan dalam penelitian ini. Sebagaimana Ekowisata menurut Fandeli et. al (2000), pada mulanya hanya bercirikan bergaul dengan alam untuk mengenali dan menikmati. Meningkatnya kesadaran manusia akan meningkatnya kerusakan/perusakan alam oleh ulah manusia sendiri, telah menumbuhkan rasa cinta kepada alam dalam diri masyarakat dan keinginan untuk sekedar menikmati telah berkembang menjadi memelihara, mengamankan dan menyayangi, yang berarti melakukan konservasi secara lengkap. Ciri-ciri ekowisata sekarang mengandung unsur utama, yaitu: konservasi, edukasi untuk berperan serta, dan pemberdayaan masyarakat setempat.

Adapun eduwisata adalah suatu program yang menggabungkan unsur kegiatan wisata dengan muatan pendidikan didalamnya. Program ini dikemas sedemikian rupa menjadikan kegiatan wisata tahunan atau kegiatan ektrakulikuler yang memiliki kualitas dan berbobot. Materi-materi dalam pemanduan telah disesuaikan dengan bobot siswa dan kurikulum pendidikan. Setiap kali mengunjungi obyek wisata akan disesuaikan dengan ketertarikan objek dan bidang ilmu yang akan dipelajari.

Yang dimaksud dengan daerah ekoeduwisata adalah daerah yang sengaja menyiapkan alam dan lingkungannya untuk dijadikan sebagai daerah kunjungan yang berdampak untuk ekonomi dan dunia pendidikan. Hal ini terkait dengan kebijakan para pemimpin daerah dan pihak pengelola objek wisata. Selain Kabupaten Siak yang bersemangat dan berusaha meraih predikat Kota Pusaka, kabupaten-kabupaten lain di Riau masih harus menyusun konsep kebijakan mereka di bidang ekoeduwisata.
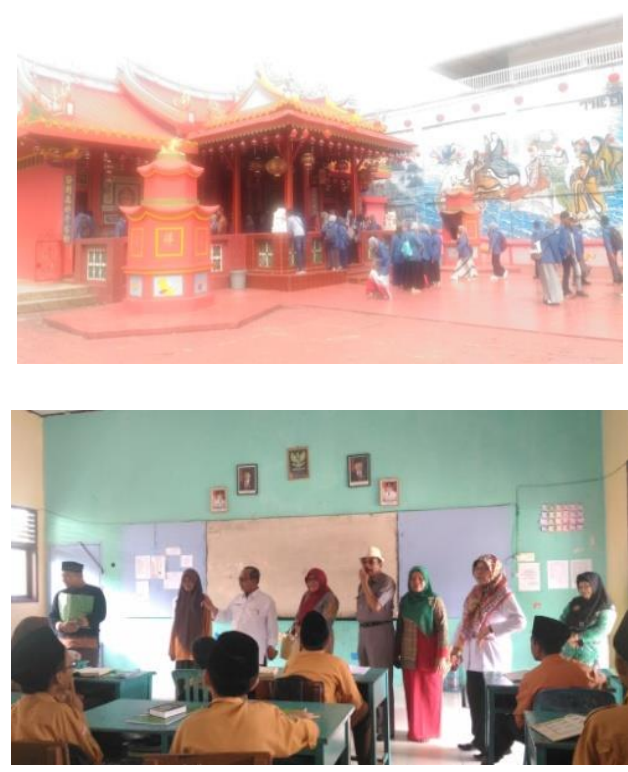

Gambar 7. Eduwisata Siak Sri Inderapura. Mahasiswa Prodi SAA Fakultas Ushuluddin UIN Suska Riau di Kelenteng (kiri); kegiatan Pengenalan peninggalan bersejarah kepada siswa SMPN Siak Sri Inderapura (kanan) 


\section{Harapan dan Upaya}

Dari pasal 85 hingga pasal 94 Undang-Undang No. 11 Tahun 2010, dapat diketahui bahwa pelestarian dan pemanfaatan cagar budaya menjadi urusan semua pihak. Menjadi urusan pemerintah jika terkait dengan perlindungan dan pengembangannya. Menjadi urusan masyarakat karena terkait dengan pemanfaatannya. Untuk lebih detil, pihak daerah dapat membuat peraturan gubernur atau bupati dan atau peraturan daerah terkait dengan pemanfaatan cagar budaya.

Pemerintah yang diwakili oleh pimpinan dinas terkait di Riau, masyarakat melalui organisasi kebudayaan dan LSM pemerhati budaya dan tokoh budayawan menginginkan jika Riau memiliki balai budaya dan cagar budaya tersendiri. Selama ini, balai budaya dan balai cagar budaya tersebut belum ada dan masih bersatu dengan Provinsi Sumatera Barat dan Kepulauan Riau di bawah koordinasi BPCB di Batusangkar. Keinginin ini dapat dipandang sebagai adanya perhatian dan keprihatinan tentang pengelolaan cagar budaya di Riau. Sejak tahun 2015, Kadisdikbud Riau pada waktu itu, Drs. Kamsol secara tidak langsung menaruh perhatian kepada perlindungan, pengembangan dan pelestarian cagar budaya.

Bahkan sebagaimana diliput oleh berbagai media cetak dan online di Pekanbaru, pada bulan Desember 2016, dalam acara Dialog Budaya Melayu, direkomendasikan adanya lembaga pelestarian cagar budaya kepada Kementerian Pendidikan dan Kebudayaan RI. Kegiatan yang berlangsung di Hotel Premiere Pekanbaru ini dihadiri oleh berbagai unsur masyarakat. Ada 15 makalah yang dibentangkan dan dari sanalah lahir rekomendasi. Di antara butir rekomendasinya dapat disimpulkan bahwa dalam rangka pelestarian dan pewarisan nilainilai budaya Melayu perlu diadakan langkahlangkah penyebarluasan, pendampingan, dan pengembangan. Mereka juga mendorong sinergi pemerintah daerah untuk lebih mengoptimalkan pelindungan, pengembangan dan pemanfaatan budaya Melayu di daerah.

Masih tentang Dialog Budaya Melayu yang banyak dilansir media cetak dan online pada tahun 2016 yang lalu, tokoh Budayawan Melayu Riau, H Tenas Effendy menyatakan bahwa keberadaan lembaga BCB di Riau sudah menjadi hal yang mutlak. Karena keberadaan BP3 Batusangkar yang sekarang berubah nama menjadi Balai Pelestarian Cagar Budaya (BPCB) meliputi Sumatera Barat, Kepri, dan Riau, terlalu luas namun jangkauannya terbatas "Usulan kita bisa dipindabkan atau dibuat khusus di Riau," ujarnya. Persoalan ini memang menjadi materi bahasan Lembaga Adat Melayu Riau. Sebab, kalau benda cagar budaya yang ada di Riau sekarang tidak terperhatikan, maka akan hilang. Riau memiliki banyak benda cagar budaya yang tersebar di hampir seluruh kabupaten/kota di Riau. Akan tetapi juga justru tidak terperhatikan. Sementara untuk pengesahan benda cagar budaya itu, meskipun Bupati dan Walikota sudah melindunginya dengan Peraturan Daerah, tetapi pengesahannya tetap melalui pusat. Ketua Dewan Kesenian Riau, H Kazzaini KS menyatakan bahwa. benda cagar budaya di Riau banyak yang tak terperhatikan, Kalau itu lambat ditangani, akan muncul penyesalan sejarah di kemudian hari. Menurutnya, benda cagar budaya yang ada di Riau itu, tidak pernah ditangani dengan baik. BPCB seperti kewalahan menangani $\mathrm{BCB}$ yang ada di wilayahnya termasuk Riau. Usulan ini tidak ditampik oleh Drs. Yoserizal Zein yang saat itu menjabat Kabid Nilai Budaya Bahasa dan Seni, Dinas Kebudayaan dan Pariwisata (Budpar) Riau.

Saat ini, Yoserizal Zein menghendaki agar kegiatan inventarisasi dan dokumentasi cagar budaya di semua kabupaten/kota di Riau dapat dituntaskan. Di sela-sela inventarisasi tersebut, perlu dilakukan pengkajian yang mendalam. Selanjutnya, registrasi cagar budaya dan penetapannya sebagai cagar budaya perlu dilakukan, setelah adanya rekomendasi penetapan cagar budaya oleh tim ahli cagar budaya Provinsi Riau. Selain cagar budaya, Kadis yang memiliki gelar magister seni (M. Sn) ini ingin mensinergikan antara peninggalan cagar budaya dengan nilai-nilai budaya non-benda atau adat. Bagaimana budaya pacu jalur atau Silat Pangean merupakan bagian tidak terpisahkan dari rumah adat di daerah Kuantan Singingi.

Bupati Siak, Syamsuar(Agustus 2017) dalam pertemuannya dengan dinas dan pihak terkait di Siak menyatakan bahwa Pemerintah Siak menginginkan peninggalan sejarah dalam berbagai bentuk di Siak dapat ditetapkan di 
bawah kewenangan Pemerintah Siak. Alasannya adalah bahwa jika ditetapkan sebagai peringkat provinsi, belum tentu cagar budaya tersebut menjadi aset yang bermanfaat maksimal bagi daerah Siak.

Dalam pertemuan terbatas terkat penetapan cagar budaya, Kepala Dinas Kebudayaan, Yoserizal Zein ( 17 Maret 2017) menyampaikan bahwa tugas Dinas Kebudayaan Provinsi Riau adalah mendukung daerah kabupaten/kota untuk mengajukan peninggalan sejarah untuk ditetapkan sebagai cagar budaya. Pada kesempatan itu, kabupaten yang mengajukan pembahasan berbagai cagar budaya di wilayahnya adalah Inderagiri Hulu, Kuantan Singingi, Rokan Hulu. Kepala Bidang Sejarah, Pelestarian Cagar Budaya dan Permuseuman, Dra. Darliana pada September 2017 yang lalu menyatakan bahwa kegiatan pengkajian berkas terkait cagar budaya dari kabupaten itu terkait dengan kesiapan daerah, karena daerahlah yang mengajukan registrasi dan ditetapkan oleh tim ahli cagar budaya. Untuk sementara, daerahdaerah yang tidak memiliki tim ahli cagar budaya telah menyerahkan pembahasannya oleh tim ahli cagar budaya provinsi berdasarkan surat keputusan bupati. Kabupaten yang telah mengajukan cagar budaya dan telah selesai pembahasannya adalah Siak, Bengkalis, Rokan Hulu, Inderagiri Hulu, Kuantan Singigi dan Kampar, walaupun yang terakhir ini hanya tiga cagar budaya yang dibahas. Beberapa kabupaten/kota belum melakukan pengkajian, seperti Kepulauan Meranti, Inderagiri Hilir, Dumai dan Pekanbaru. Menurut Dra. Darliana, belum adanya pengajuan karena belum dilakukannya pengkajian oleh dinas terkait di daerah.

Kepala kantor Kebudayaan dan Pariwisata Kota Pekanbaru, pertengahan Agustus 2017, pernah menyampaikan keinginannya bahwa di antara banyaknya peninggalan bersejarah di Pekanbaru, harus ada yang ditindaklanjuti dengan penetapan sebagai cagar budaya. Namun upaya ini memerlukan waktu tertentu dan keseriusan. Belakangan, Disbudpar Kota Pekanbaru melakukan inventarisasi berbagai peninggalan sejarah dan mengajukannya ke Dinas Provinsi Riau untuk dibahas dan direkomendasikan sebagai cagar budaya.
Upaya menuju eduwisata mestinya tampak jelas dan nyata jika cagar budaya terletak tidak jauh dari lokasi pendidikan. Artinya dunia pendidikan sendiri tidak hanya sebagai penerima manfaat dari adanya cagar budaya di sekitarnya, tetapi juga sebagai subjek yang akan berperan dalam pengelolaan cagar budaya untuk kepentingan pendidikan. Kenyataannya, keberadaan Vrouwenkamp Bangkinang yang berada di areal SD 08 Salo misalnya, tidak terkait sama sekali dengan sekolah dan lingkungannya. Anak-anak murid di situ tidak tahu apa dan bagaimana struktur bersejarah yang terbentang di areal bermain mereka. Orangtua yang datang mengantar dan menjemput anak-anak mereka juga tidak tahu tentang keberadaan struktur tersebut. Ketika ditanyakan kepada pihak DPRD Kampar, Ahmad Fikri (11/11/2017), ia menyampaikan bahwa kabupaten Kampar memiliki visi di bidang kebudayaan, termasuk kebudayaan tidak bergerak dalam kategori cagar budaya. Namun, kemungkinan besar adalah bahwa kebijakan bidang ini bukan prioritas. Hal ini senada dengan komentar Afrizal, salah seorang petugas dari BPCB Batusangkar yang sehari-hari bertugas di areal Percandian Muara Takus. Menurutnya, sekalipun PercandianMuara Takus aset nasional, tetapi tingkat kunjungannya musiman, seperti masa liburan sekolah atau liburan hari besar. Kalau liburan akhir minggu pengunjung tidaklah seberapa. Anak-anak sekolah memang menjadi pengunjung terbanyak, tetapi zona pengembangannya sangat kurang dimanfaatkan untuk peningkatan ekonomi masyarakat. Areal itu tidak dimanfaatkan dengan baik. Memang ada perbaikan di zona penyanggah, yaitu pembongkaran bangunanbangunan semi permanen di daerah dekat situs, untuk dimundurkan ke zona pengembangan dalam rangka pelestarian cagar budaya tersebut. Sementara menurut pihak BPCB Batusangkar, Agus Triyono, zoning untuk percandian sudah dilakukan tetapi bermasalah dengan pembebasan tanah di sekitar percandian.

Komunitas pegiat peninggalan sejarah kadang lahir dari kesadaran sejumlah orang, misalnya Pekanbaru Heritage Walk. Mungkin karena para inisiatornya berkecimpung dalam bisnis tur. Sehingga, mereka memanfaatkan peninggalan sejarah sebagai destinasi tur sekaligus untuk memperkenalkan berbagai keragaman budaya di 
Pekanbaru melalui program jalan-jalan. Komunitas pemerhati peninggalan sejarah ada juga muncul dari sejumlah pribadi yang memiliki keinginan yang sama dalam rangka mengangkat potensi daerah menuju kesejahteraan ekonomi. Mereka menjadikan peninggalan sejarah dan budaya sebagai bagian pelengkap paket agrowisata yang menjadi tujuan pokok mereka membangun komunitas.

Di daerah Senapelan, daerah lama dan padat ini juga tidak jauh berbeda. Di daerah Pekanbaru berawal ini terdapat objek kunjungan wisata belanja, yaitu Pasar Bawah. Sayangnya, kesenangan berbelanja tidak dimaksimalkan dan dikelola dengan wisata budaya dan lingkungan senapelan. Padahal daerah Pasar Bawah dapat ditingkatkan menjadi kawasan Senapelan, dengan masjid, makam, rumah tua bersejarah, rumah singgah, gudang garam, pelabuhan pelindo, makam-makam tua, gedung-gedung bersejarah dan lain-lain lengkap dengan kuliner khas melayu. Rumah batin senapelan sendiri memiliki nilai sejarah dan tradisi yang dapat diberdayakan sebagai bagian dari wisata kawasan senapelan. Gagasan ini hanya ada dalam penelitian ilmiah para dosen di kampus-kampus negeri di Pekanbaru atau menjadi kerinduan kalangan-kalangan tertentu saja. Sampai tahun 2017, belum ada upaya nyata dari pemerintah kota untuk membenahi daerah Senapelan ini. Agaknya ada perasaan trauma di kalangan banyak pihak terkait dengan pemugaran atau renovasi cagar budaya, karena kasus malrenovasi masjid raya yang belum tuntas kasusnya hingga sekarang. Kerugian negara dapat dihitung, namun kerugian sejarah dan budaya tidak dapat dihitung. Mungkin itulah sebabnya berbagai pihak cukup berhati-hati untuk tidak menyentuh pemugaran kawasan yang memiliki cagar budaya di dalamnya, bahkan sekalipun cagar budaya tersebut belum ditetapkan, seperti rumah penitipan sepeda, rumah Haji Sulaiman India, rumah tempat rapat SDI dan lain-lain.

\section{PENUTUP}

Pelestarian terhadap peninggalan sejarah cagar budaya merupakan amanat Undang-Undang Nomor 11 Tahun 2010. Pelestarian mensyaratkan pemanfaatan, pemanfaatan meniscayakan keterlibatan masyarakat.
Pemerintah sebagai motivator, dinamisator dan fasilitator memberikan ruang bagi masyarakat atau komunitas untuk memanfaatkan cagar budaya berbasis lingkungan. Artinya, setiap upaya pemanfaatan cagar budaya haruslah memperhatikan kelestarian alam. Aspek edukasi untuk setiap kebijakan wisata harus ada dan dimasukkan ke dalam kurikulum dan pembelajaran di sekolah. Di Riau, terumata di Kabupaten Siak, Kabupaten Kampar dan Pekanbaru, sudah mulai bermunculan upaya menjadikan cagar budaya lengkap dengan ekoeduwisatanya sebagai bagian destinasi wisata. Upaya-upaya yang dilakukan oleh komunitas pemuda dan masyarakat ini perlu bimbingan dan dampingan. Di sini perang perguruan tinggi dan asosiasi terkait.

Kebijakan pemerintah daerah di Riau berbeda-beda terkait dengan pelestarian cagar budaya. Ada yang fokus dan prioritas, seperti Kabupaten Siak, namun ada yang terkesan belum mengandalkan sektor pariwisata yang berbasis alam sebagai aset daerah. Ada kelompok masyarakat yang aktif dalam pemanfaatan cagar budaya seperti komunitasi pemuda di Pulau Belimbing, Siak Heritage Community, Pekanbaru Heritage Walk dan Tapung Heritage, tetapi mereka belum mendapat perhatian dan pemberdayaan dari pemerintah. Oleh karena itu, kami merekomendasikan agar pemerintah melalui dinas terkait perlu mensosialisasikan secara masif tentang perlunya pelestarian peninggalan sejarah jenis cagar budaya melalui pemanfaatannya dalam ekoeduwisata. ***

\section{DAFTAR PUSTAKA}

Amrun, Jarir. 2016. Wartawan-penulis dalam http://riaupos. co.

Van-Anrooij, H. A. Hijmans. 1885. "Nota Omtrent het Rijk van Siak", Tijdschriftvoor Indische Taal-, Land-, en Volkenkunde (TBG). Deel XXX; pp. 260-390.

BalaiArkeologi Medan. 1998. BerkalaArkeologi Sangkhakala.

Data Dinas Kebudayaan Provinsi Riau. 2017. Draft Naskah Rekomendasi Cagar Budaya.

Data Dinas Pendidikan dan Kebudayaan Provinsi Riau. 2016. Draft Naskah Rekomendasi Cagar Budaya. 
Departemen Pendidikan dan Kebudayaan Direktoral Jenderal Kebudayaan Bagian Proyek Pembinaan Permuseuman Riau. 1997. Laporan Pengadaan Benda-Benda Seni Budaya, Tahun Anggaran 1996/1997. Pekanbaru.

Dokumen Rapat Dengar Pendapat Pemerhati CB Riau dengan DPRD tentang Masjid Raya Pekanbaru, 2016.

Ermiliansa, Dedien, Adji Samekto, and Hartuti Purnaweni. 2014. "Peran Prenjak Dalam Mewujudkan Daerah Konservasi Berbasis Eco Edu Wisata Mangrove di Dusun Tapak, Tugurejo, Kota Semarang. " Ekosains. 6. 1.

Fandeli, Chafid. 2000. "Pengertian dan konsep dasar ekowisata. " Di dalam: Fandeli, C. , dan Mukblison, Editor. Pengusahaan Ekowisata. Yogyakarta: Fakultas Kehutanan UGM, Unit KSDA DIY, Pustaka Pelajar.

Firzal, Yohannes. Pengembangan Kawasan Tepian Sungai sebagai Kawasan Buniness Baru Kota Pekanbaru. Ejournal. www. localwisdom. ucoz. com/id/0/21;

2011. Tipologi Bangunan Tua. Ejournal. Vol. 3 No. 2. hlm. 33-42. 2011.

FR, Halim. 2013. "Fasilitas Eduwisata Sejarah Perjuangan Kota Surabaya". eDimensi Arsitektur Petra 1. 2 (2013): 118-124.

Haan, F. de, (1896), Naarmidden Sumatra in 1684, Batavia-'s Hage, Albrecht \& Co. -M. Nijhoff. 40p. 8vo wrs. TijdschriftvoorIndischeTaal-, Land- en Volkenkunde, Deel 39.

Garraghan, Gilbert J. 1957. A Guide to Historical Method. Vol. I \& II. New York: Fordham University Press.

Gramberg, J. S. S. 1864. "Reis naarSiak", TBG. Deel XIII; pp. 498-522.

Haryono, Timbul. $1986 . \quad$ Relief danPatungSingaPadaCandi-

CandiPeriodeJawaTengah :Penelitian AtasFungsidan Pengertiannya. LaporanPenelitian. Yogyakarta.

Herlina, Nina. 2008. Metode Sejarah. Bandung: Historika.

Kartodirdjo, Sartono. 1992. Pendekatan Ilmu Sosial dalam Metodologi Sejarah. Jakarta: Gramedia.

Kasiri. 1993. "SoemanHs: Guru yangBerjiwa Guru", dalamMajalahTempo: MemoarSenaraiKiprahSejarah. Jakarta: PustakaUtamaGrafiti. No. 262/93. Hlm. 89118.
Kempers, A. J. Bernet. 1959. Ancient Indonesian Art. Cambridge, Massachusetts: Harvard University Press.

Kuntowijoyo. 1995. Ilmu Sejarah: Pengantar. Yogyakarta: Bentang Budaya.

Lewis, Bernard. 2009. Sejarah: Dïngat, Ditemukan Kembali, Ditemuciptakan. Terjemahan Bambang A. Widyanto. Yogyakarta: Ombak.

Lutfi, Mukhtar, dkk. 1999. Sejarah Riau. Reproduksi. Pekanbaru: Pemerintah Provinsi Riau.

Schadee,W. H. M. 1918, Geschiedenis van Sumatera Ootskust, Madedeeling 2. Deel 1. Amsterdam: Oostkust van Sumatra Instituut.

Suryadi, Hery, Tuti Khairani, Auradian Marta. 2016. Kebijakan Revialisasi Kawasan Pasar Bawah Sebagai Kawasan Wisata Cagar Budaya di Kota Pekanbaru. Pekanbaru. Fisipol Universitas Riau.

Surat Keputusan Menteri Pendidikan, Kebudayaan dan Pariwisata RI, Nomor KM. 13/PW. 007/MKP/2004 tanggal 3 Maret 2014 tentang penetapan cagar budaya di Riau.

Surat Keputusan Menteri Pendidikan dan Kebudyaaan Nomor 209/M/2917 tanggal 3 Agustus 2017 tentang penurunan statusnya dari bangunan cagar budaya menjadi struktur.

Suwardi MS dan Kamaruddin. 2016. Sejarah Lokal Riau. Pekanbaru. Pemeritanh Provinsi Riau.

Wan Ghalib, Isjoni. 2004. Dari Batin Senapelan ke Bandaraya Pekanbaru. Pekanbaru. MSI.

Sugiharta, Sri dan Agoes Tri Mulyono. 2017. "Warisan Arkeologi Perkotaan di Kawasan Bandar Senapelan"dalam Sri Sugiharta. Sumatera Silang Budaya: Kontestasi Nilai-Nilai Historis, Arkeologis, dan Antropologis serta Upaya Pelestarian Cagar Budaya. Batusangkar. BPCB. .

Moens, J. L. 1937. Srivijayva enKatana. Batavia: Tijdschrift voorIndischeTall,Land en Volkenkunde. Jilid LXXVII. 1937.

Schnitger. Forgotten Kingdoms in Sumatra, Brill Archive

Siagian, Renville. 2002. Candi sebagai Warisan Seni dan Budaya Indonesia. Yogyakarta: Yayasan Cempaka Kencana.

Sjamsuddin, Helius. 2007. Metodologi Sejarah. Terj. S. Aji. Yogyakarta: Ombak.

Soekmono. 1981. PengantarSejarabKebudayaan Indonesia 2. Yogyakarta: Kanisius. 
Wilaela: Pemanfaatan peninggalan sejarah di Riau ...

1974. Candi, FungsidanPengertiannya.

Disertasi. Jakarta.

Suaka PSP Prov. Sumbardan Riau. 1995. BuletinArkeologi Amoghapasa. Batusangkar.

Undang-Undang RI Nomor 11 Tahun 2010 TentangCagarBudaya.

Tanudirjo, Daud Aris. 2003. "Warisan Budaya untuk Semua. Arah Kebijakan Pengelola Warisan Budaya Indonesia di Masa Mendatang. "Makalah Kongres Kebudayaan $V$. Bukittinggi.

Wilaela. "Encik Hasnah: Menekat Budaya." Mutiara Yang Terjaring. Pekanbaru: Pusdatin Puanri. 2007. hal. 67-84.

Yusuf, Ahmad et al. 1992. Sultan SyarifKasim II: Raja TerakbirKerajaanSiak Sri Inderapura: Pemerintahan, Perjuangan, Warisan, Pekanbaru: Pemprop Riau.

Yzerman, J. W. Beschrijuing Van die BoeddhistischeBounwerkenteMoearaTakoes.

Padang, Desember 1989

Zewita, Maria. 2010. Kajian Sumberdaya Perairan Situ IPB bagi Pengembangan Edunisata di Kampus $I P B$, Dramaga, Bogor.

http://repository. uinri. ac. id/. http://melayuonline. com.

http://tripriau. com/2206/mengenal-jejakjejaksejarah-pekanbaru-di-kawasan-lamasenapelan. html/

Afrizal. 2016. Petugas dari BPCB Batusangkar di areal Percandian Muara Takus.

Anita (lahir 1974), cucu dari H. Sulaiman, Jalan Kesehatan No. 29 Pekanbaru.

Arthum Artha, 2013 Laporan Hasil Observasi. Kompleks Pemakaman Senapelan Pekanbaru.

Dadang, juru pelihara dan pemuda pemerhati benda bersejarah Senapelan.

Darliana, Dra. M. Si. 2017. Kabid Sejarah, Cagar Budaya dan Permuseuman Provinsi Riau. Hasil Diskusi di Golden Tulip 14 Desember 2017.

Didiek Supriadi. 2017. Penjaga SDn 008 Salo Kampar.

Habibi. Tapung Heritage.

Jamil, O. K. Nizami. Drs. 2017. Ketua LAM Riau dan LAM Siak serta Tim Ahli Cagar Budaya Riau.

Mujahiddin, Ahmad. Prof. Dr. , M. Ag. 2017. Penasehat di Taman Agrowisata Desa Sungai Geringging, Kulim. Taman buah seluar \pm 29 ha, dimiliki dan dikelola masyarakat.
Mahadar, M. Si. 2016-2017. Kepala Bidang Kebudayaan dan Pariwisata.

Manaf (21 tahun). 2017. Mahasiswa dalam persiapan wisuda. Bersama pemuda-pemuda di daerah Belimbing sedang membangun komunitas yang menginginkan Kabupaten Kampar menjadi destinasi wisata alam, agrowisata dan kuliner.

Nasution, Achmad Al Azhari. Kepala Seksi Cagar Budaya Bidang Sejarah, Pelestarian Cagar Budaya dan Permuseuman Dinas Kebudayaan Provinsi Riau.

Putra, Wan. (30 tahun). Siak Heritage Community (SHC). Memiliki banyak koleksi naskah dan foto tua tentang Kerajaan Siak. Rajin melakukan sosialisasi tentang khazanah sejarah Siak melalui medsos dan tourguide yang baik untuk berbagai objek destinasi wisata di Siak.

Suparman (26 Tahun). Penggiat agrowisata di Pulau Belimbing, Kabupaten Kampar.

Syamsuar. Bupati Siak. 2017. Pengarahannya untuk membangun sinergi dan komitmen bersama menjadikan Siak sebagai Kota Pusaka.

Suwardi, MS. Kamis 14 Desember 2017 di Golden Tulip Hotel.

Wati, Nurhamida. 2017. Koordinator Koleksi Museum Daerah Sang Nila Utama.

Wilaela, 2017. Hasil Observasi bersama tim Dinas Kebudayaan Kota Pekanbaru.

Zein, Yoserizal. Drs. Kadis Kebudayaan Provinsi Riau. Pengantar-Pengantarnya pada Rapat dan Diskusi Terfokus TACB. 